Volume and Issues Obtainable at Center for Sustainability Research and Consultancy

Journal of Business and Social Review in Emerging Economies

ISSN: 2519-089X (E): 2519-0326

Volume 6: No. 3, 2020

Journal homepage: www.publishing.globalcsrc.org/jbsee

\title{
A Framework for Assessing Impact of Brand Personality on Customer Satisfaction: The Moderating Role of Gender and Age
}

\author{
${ }^{1}$ Zara Hayat, ${ }^{2}$ Sahar Hayat, ${ }^{3}$ Saba Hayat, ${ }^{4}$ Hayat Muhammad Awan \\ ${ }^{1 \& 3}$ Visiting faculty, Bahauddin Zakariya University, Multan, Pakistan \\ ${ }^{2}$ Lecturer, NFC-IT, Multan, Pakistan \\ ${ }^{4}$ HOD, Department of Business Administration, Air University Multan Campus, Pakistan, hma@aumc.edu.pk
}

\begin{tabular}{l} 
ARTICLE DETAILS \\
\hline History \\
Revised format: August 2020 \\
Available Online: September \\
2020
\end{tabular}

\section{Keywords}

Brand Personality, Customer Satisfaction, Customer Gender,

Age

JEL Classification

M3, M31

\section{ABSTRACT}

This study develops an empirical examination of brand personalities in cellular phone sector of Pakistan as a predictor of customer satisfaction. The purpose of this research is to develop a framework that how brand personality of cell phone can increase the level of customer satisfaction. This study also aims to test the moderating role of demographic characteristics (Gender and Age) in the relationship between brand personalities and customer satisfaction.

A sample of 300 cell phone users from 5 cities of Pakistan is selected .Based on the survey of consumers of cell phones; the authors checked the effect of brand personality on customer satisfaction. Moderation Analysis was used to check the demographic characteristics effect (Gender and Age) on satisfaction and brand personality relationship. Results indicated that due to different dimensions of brand personality of cell phones, customer observed massive satisfaction level. So, since customer faced more satisfaction, they signified more intention towards brand. Further, our research also confirmed the moderating role of Customer Age. This study reveals that when cell phone manufacturing companies invest the human characteristics into their brand so that personality of their brand can develop, their customers can be more loyal towards organization and their level of satisfaction increased. Marketers and Brand Managers must develop marketing and advertisement activities in line with the personality of their cell phone brands.

Originality / Value - Literature on post-purchase behavior and brand personality reveals that how different dimensions of brand personality can increase customer satisfaction and the role of age as a moderator. Our research adds to the literature of brand personality.

\section{OPEN ACCESS}

(C) 2020 Center for Sustainability Research and Consultancy Pakistan under a Creative Commons Attribution-NonCommercial-ShareAlike 4.0

Corresponding author's email address: hma@aumc.edu.pk

Recommended citation: Zara, H., Sahar, H., Saba, H., \& Hayat, M. A. (2020). A framework for assessing impact of brand personality on customer satisfaction: The moderating role of gender and age. Journal of Business and Social Review in Emerging Economies, 6(3), 999-1014 


\section{Introduction}

In the context of Cell Phone manufacturing sector, organizations have been facing a lot of openings for magnetism of customers. Companies have lot of chances to pull the brand's podium and exhibit their personalities in front to the customers. Marketing guys have been trying to brace the bindings among their brands and consumers. Recently, it has been noticed that customers are influenced by those brands which have some resemblance with their traits and persona. Exclusively, this sort of association considered as optimistic and expectants in the perception of marketing. Numerous researchers have been focusing the worthiness of brand personality as a center of attention (Aaker, 2004; Grohmann, 2009). On the other sides, research has publicized that the symbolizations of products or brands always play a dominant role during purchase process and tangible product's features and functions are considered as secondary aspect (Holt, 1995; Levy, 1959). At the same time, different studies have viewpoint that loyal customers can pay whatever price and they are not as much of price sensitive (Krishnamurthi and Raj, 1991).

Economies of scale towards a huge cluster of trustworthy customers developed a reduction in marketing cost as well. On the other hand, some researches summarized that the company's precious customer collections are those who are loyal and can spend more than others. So, humanistic characteristics of brands can employ that precious customer group more loyal than others (Zeithaml et al., 1996). Additionally, improvement in loyalty and equality of brands is an outcome of brand personality, which also fortified the interactions of customers with brands (Govers\&Schoormans, 2005). However, the effect of the traits of brand has little investigated in this context. Nevertheless, unfinished parts of the prose on brand personality also exist. Thus it has now unavoidable for marketing professionals to overlook the importance of brand personality, customer satisfactions and loyalty. It is also unidentified that can cell phone manufacturing organizations get competitive advantage after instituting human personality's characteristics in cell phone brands? In branding research, construct as brand personality has attained a lot of which has made an association between multiple human characteristics and brand (Aaker, 2004). However, the topic of moderator variables was mostly ignored between the relationship of customer satisfaction and personality of brand. The importance of demographic variable is missing in the previous studies (Awad, 2011; Homberg and Giering, 2001). Moreover, further research be conducted in order to assess the ability of personality traits that influence purchasing decisions stated by Caprara et al. (2001). Furthermore, the researchers noted that different standards of personality characteristics are still have to divide with respect to ethnicity and geography. So, an essential upcoming subject matter of research is the moderating role of gender and customer age. Recently, Awad (2011) mentioned in his research on age, income and education that despite the marginal differences, it still helps to define characteristics of consumer. Additionally, moderation role of demographic characteristics, which can influence the relationship of satisfaction and consumer behavior examined by Mittal and Kamakura, (2001).

Thus, the intention of this research is to offer additional imminent for brand personality and satisfaction relationship after investigation of demographic characteristics moderation on this connection. Precisely, satisfaction and brand personality linkage in context of cell phone sector has studied, moreover, the study has also examined the demographic characteristics impact as moderator.

This research will answer the following research questions:

- Does there any relationship exist between brand personality and satisfaction of customer?

- Is it possible for customer age and customer gender to influence the potency of relationship between personality of a brand and satisfaction of customer?

Inside our research, we believed that organizations can only be successful in order to satisfy their customers if they thoughtfully regard brand personality as principal cause and consumer chase their own personalities in line with their favorite cell phone brands. At the outset, we investigated the influence of sincerity, excitement and sophistication, considering three constructs / dimensions of brand personalities, on demographics (Gender and Age) characteristics as to see if they are affecting the relationship between brand personality dimension \& customer satisfaction. Our research deliberated that human personality characteristics in cell phone brands can wield the amplification of satisfaction. Research also tried to formulate some inputs to already existed literature along with viable outlines which supports 
business professionals to build up the loyalty of customers and satisfaction in those cell phones brands, which depict the customer's own human personalities.

\section{Theoretical Background and Literature Review \\ 2.1 Brand Personality}

When a brand is measured or related with collection of human traits, is entitled as Brand Personality (Aaker, 1993). When perceptions of a brand by and large match with the customer's traits, it means that brand personality works (Batra, Lehmann and Singh, 1993). Likewise, different researchers like Plummer (1985) and Durgee (1988) contend that brands, similar to people, can likewise be relegated personality profiles that are characterized through a progression of qualities. Analysts have found that brand personality underpins a buyer to uncover his or herself), a perfect self (Malhotra et al, 2006), or precise parts of the self through utilization of a brand. Brands have their own specific identities. Shoppers may regard brands as genuine individuals. For this situation, buyers will expect the individuals' words, disposition, conduct or contemplations thus on to meet their individual identity characteristics also asserted that typical utilization of brands is workable as buyers by and large ingrain a brand with human identity attributes. Aaker et al (2004) prominent that purchasers perceive that brands have five unmistakable identity measurements: sincerity (residential, genuine, veritable, and lively), excitement (brave, vivacious, inventive, state-ofthe-art), competence (dependable, mindful, tried and true, effective), sophistication (exciting, grandiose, beguiling, sentimental) and ruggedness (extreme, solid, outdoorsy, tough). Brand Personality is considered as an aspect that exerts influences on customer alternatives and fondness. We can say that it is a component that produces esteem for the purchaser and for the organization as well.

Different researches identified that purchasers select brands that have similitude with their needs and identity attributes. Brand identity qualities are framed from purchaser experience and any immediate or backhanded contact in the middle of customers and the brand. After keen comprehension of the brand's identity, marketers can better comprehend the significance, strength and continuance of a specific brand identity and they can verify that how this identity affects on buy expectations and practices.

Brand personality may have an imperative and vital concern for both marketers and consumers. Most of the time, marketing activities are designed and perceive a brand identity and fortifying the correspondence between brand and the customer (Govers and Schoormans, 2005) so that satisfaction and brand's equity can be more enhanced. Brand personality facilitates organizations to make special and great impressions in shoppers' psyche so that brand's equity can be more enhanced. (Johnson, Soutar, \& Sweeney, 2000). In the perspective of advertisers, the personality of a brand is a fundamental part of the picture and value of the brand and in shoppers' brains, and is applicable to brand esteem. Companies and consumers can establish close relationships with each other's, if brand personality is steady, forceful, unique and enviable. As a result, marketers must consider personality of brand as a compelling method for recognizing from their rivals and improve the adequacy of marketing (Sung \& Kim, 2010).Mengxia (2007) inspected the Influence of the personality of brand on customers' image inclination, friendship, dedication and acquiring proposition. Result of his learning demonstrates that brand personality would have a positive impact on brand inclination, unwaveringness and buy expectation.

On the other side, the Brand's personality construct as an idea of shopper test brain science had been proposed as an essential predecessor of consumer loyalty. Different scholars elaborated that the social and self-expressive normal for the brand personality may represent its cooperation as a forerunner of satisfaction and unwaveringness. In this way, brand personality was thought to be dead set close by consumer loyalty as focal determinants of client dependability. On the same lines, some studies also revealed the same outcomes while focusing the impact of brand personality. Different researches showed that brand personality might decidedly influence brand reorganization, brand relationship quality ( Aaker et al., 2004), brand influence, brand trust (Sung \& Kim, 2010), fulfillment, and brand dedication (Brakus et al., 2009). Brand personality is additionally found to build shoppers' self-importance (Levy, 1959) and give passionate parts of brands (Landon, 1974). Well-trustworthy brand personality can help customers to fortify their image enthusiastic ties, improve inclination, trust and dedication (Siguaw, Mattila, \& Austin, 1999).

There distributed a crisp study predominantly concentrates on the sexual orientation perspectives (male/female) of 
brand personality. It altogether demonstrated that when there is closeness or similarity between supposed brand personality and the self-idea of the shopper, reactions are more hopeful \& valuable and it goes to a positive mentality to the brand, inclination for the brand over contending brands, an abnormal state of warmth and trust create and a high level of steadfastness to the brand as far as demeanor and conduct developed (Grohmann, 2009).

\subsection{Brand Personality and Customer Satisfaction}

Previously as we argued, dimensions of Brand Personalities can influence the level of satisfaction (Brakus et al., 2009; Solomon et al., 2006; Park et al., 2012).

Buyer satisfaction has been viewed as an imperative promoting idea to meet buyers' necessities and goals. (Howard, Sheth, 1969) characterized purchaser fulfillment as "the purchaser's condition of being satisfactorily or deficiently compensated for the penances he has experienced". It focused on the consequence of penances as far as purchasers can tell. Oliver(1981) implied satisfaction as "the diagram mental state occurring when the inclination enveloping disconfirmed goals is coupled with the customer's previous feelings about the use experience". At the point when customers buy a product, they will get to be fulfilled on the off chance that they confirm what they bought is as per or surpasses their pre purchase desires. Examination has demonstrated that satisfied buyers are prone to perform postbuy conduct (Cardozo, 1965). Online shopper connections are less demanding to make if customers can add to an abnormal state of satisfaction (Floh\&Treiblmaier, 2006; Wang \& Head, 2007). Satisfaction catches buyers' happiness on their observations and past encounters to a certain brand (Anderson et al, 1994). In this study, we concentrated on purchasers' satisfaction toward brands as they take after their personality attributes into their most loved mobile phone brands. Lin (2009) likewise found that distinctive measurements of brand personality may set critical effects on satisfaction in the context of internet games. A reason that brand personality influences fulfillment is that brand personality can convey worth to buyers (Brakus et al., 2009). On one hand, brand personality is required to convey separation to shoppers and expand their inclination. Then again, customers can communicate through selecting a brand with certain acculturated attributes (Aaker et al, 2004). In light of these discoveries, we expected that brand personality in phone brands might likewise fortify customer satisfaction. A purchaser is prone to frame positive emotions toward a brand, which is connected with adapted substance. For this situation, we expected that if the purchaser sees that the brand s/he takes after is genuine, skilled, energizing, or complex, then s/he is more inclined to wind up fulfilled by the brand. From above, H1 (a), H1 (b) \& H1 (c) are developed:

H1 (a): Sincerity in Brand shall boast encouraging effect towards satisfaction of customer.

H1 (b): Brand's usage Excitement shall boast encouraging effect towards satisfaction of customer.

H1 (c): Brand's Sophistication will have positive impact on consumer satisfaction.

\subsection{Demographics Characteristics}

Taking into account a survey of the writing identified with individual determinants of purchasing conduct, two demographic qualities have directing effect on the linkage between brand personality and consumer satisfaction. The things in these two demographic attributes were picked in light of the Aaker's (2004) human personality definition that generates the development of brand personality. Aaker characterized the related brand personality as an arrangement of "human demographic attributes like age, sex, race and pay". Each of these components has been discovered to be pertinent in the connection of consumer loyalty and past studies.

\subsection{Gender}

Study on sexual orientation impact toward purchaser purchasing conduct has pulled in some examination interest (e.g., Matzler et al, 2006; Chen and Dahillon, 2003; Venkatesh et al., 2001; Jasper et al, 1992). Product satisfaction has a critical impact on proposition to repurchase at the same wholesaler for men yet not for ladies (Homburg \& Giering, 2001). In any case, ladies is more included in acquiring exercises and give careful consideration to the counseling administrations contrasted with men stated by Slama and Tashlian, (1985) (Gilbert \& Warren, 1995).

These contentions lead to the recommendation that sexual characteristics may direct the linkages of contentment and brand personality. As a sample, one may anticipate that the devotion impact of satisfaction with the business 
procedure is more grounded for ladies than for men, though the effect of brand personality to contentment may be more grounded for men. Another great illustration is manly (e.g. Malboro) and ladylike (e.g. Virginia Slims) brand personality fits the formation of brand fit in a brand augmentation and expanded buy propositions. Mostly prior research have demonstrated that gender and personality are connected with satisfaction levels.

Current research expect that brand personality impacts towards customer liking increment with the purchaser's sexual orientation. From above, $H 2$ is developed:

H2: Customer gender will have increasing influence on the relationship between brand personality and customer satisfaction

\subsection{Age}

The factor of age also considered by researchers as one of the demographic characteristic (Smith \& Baltes, 1990; Cooilet al., 2007; Bauman et al., 2005; Homburg \& Giering, 2001). Mostly it concludes that information dispensation turn down with age. More seasoned individuals have confined data preparing capacities, thusly their responses to satisfaction movements may additionally change. Likewise, towards expressive product younger pay more attention as compare to older natives (Henry, 2002). Goldberg, et al., (1998) in context of brand personality discovers normal connections towards demographic variables including age and five personality measurements or dimensions. Moreover, age and literacy assume a real part in deciding the diverse customers view regarding satisfaction and steadfastness (Caruana, 2002).

Therefore, age is recommended as moderator between satisfaction and brand personality. From above, $H 3$ is developed:

H3: Change in customer age will have impact on the relationship between brand personality and customer satisfaction level.

Upon the basis of literature, we developed following framework as the foundation for the paper, over which we tested the hypotheses outlined above.

\section{Brand Personalities}

\section{Methodology}

\subsection{Research Design \& Product Selection:}

In order to test the proposed hypothesis, a questionnaire was prepared consist of five points likert scale. Foremost, respondents had to submit answers of demographic questions along with some questions about the brand of cell phones under their current usage.

Questionnaire was developed to collect responses from the cell phone customers who had bought their cell phones 
manufactured by different companies. Questionnaire was distributed in five big cities of Pakistan (Islamabad, Karachi, Lahore, Faisalabad and Multan). Responses were only collected from those customers who have been using their cell phones for at least last one year.

As we discussed earlier, we urged for a product of high involvement (Product Involvement) in order to analyze our research's constructs. Such a product that a consumer experiences it at least once and that product must be manufactured as well as publicized by handful companies. Most importantly, that product must have self-image, which must be perceived by consumers as influential factors. On these foundations, we selected Cell Phones as product of our research. As we all know that cell phones have become essential elements of everybody's life and consumer of cell phones assess the pros \& corns. Furthermore, as these cell phones are regularly used by consumers, so its evaluation process is relatively easy for consumers. As a result, we can conclude that cell phones brands have high involvement during purchase efforts. So, it was very much appropriate for our research.

\subsection{Population}

We selected mobile phone consumers of five cities as population of study.We regarded occupation, gender \& age consider demographics. Critical point is that all consumers of mobile phones at least buy a cell phone once in their life.

We gathered data on 300 questionnaires. The statistical population regarding this research includes the colleges \& universities students, employees, own businessmen \& households. . Systematic sampling technique is being used in this study. Using this sampling technique, 300 questionnaires were distributed and only 203 questionnaires were usable.

\subsection{Data Collection}

Data from customers was collected from self-administered paper-pencil questionnaire having 27 questions. All the questions included in the questionnaire were close ended. As (Schmidt \& Hollensen, 2006) noted that close ended questionnaires are very simple to administer and by and large, generate quick end conclusions. All the questionnaires were personally handed over to collect the data.

\section{Data Analysis and Results}

4.1 Descriptive Analysis:

Table shows the result of our sample demographics as follows.

\section{Sample Demographics}

\begin{tabular}{lcrr} 
Characteristics & Categories & Frequencies & \% \\
\hline \multirow{2}{*}{ Gender } & Male & 122 & 60.1 \\
Age & Female & 81 & 39.9 \\
& 18-25 Years & 113 & 55.7 \\
& 25-35 Years & 74 & 36.5 \\
35-45 Years & 14 & 6.9 \\
Occupations & 45 Years \& Above & 2 & 1.0 \\
& Employee & 102 & 50.2 \\
& Student & 85 & 41.9 \\
\multirow{3}{*}{ Brands of Cell Phone } & Households & 13 & 6.4 \\
& Own Business & 3 & 1.5 \\
& Nokia & 65 & 32.0 \\
& Samsung & 78 & 38.4 \\
& iPhone & 12 & 5.9 \\
& HTC & 6 & 3.0 \\
& Q Mobile & 20 & 9.9 \\
& Huawei & 22 & 10.8 \\
\hline
\end{tabular}

The client populace breakout on the premise of sex was $60.1 \%$ as males and $39.9 \%$ as females. In females, the clients 
were for the most part understudies. While, the males had a place with diverse foundations, for example, school or college under studies, jobholders, businesspeople and experts.

\subsection{Reliability of Data Analysis}

Research dependability is defined as the self-confidence inside research. The more the self-confidence, the more authentic and reliable the research is. The reliability analysis has been conducted on the study to get the Cronbach's coefficient alpha. The resultant score is 0.792 which is closer to 1 and shows highly reliable research analysis.

\section{Reliability Statistics}

Cronbach's Alpha

0.792
Number of Items

\subsection{Analytical Hierarchy Process}

Saaty (1990) introduced AHP which is also known as MCDM (multi criteria decision making tool). Its purpose is to make decision by keeping some decision criteria in mind. There were many methods among which priority based, distance between decision making, outranking etc. are the most common. Hierarchy of determinants is obtained after applying AHP, where the upper hierarchy helps in decision making process. Next to upper hierarchy is second hierarchy level known as selection criteria and finally there was bottom level hierarchy presenting alternative decisions to be considered.

The analytical hierarchy shows the relative importance of items related to brand personalities marketing strategies in developing customer satisfaction. The distribution of 7 items is shown in Table as follows

Analytical Hierarchy Process for Impact of Brand Personality

\begin{tabular}{|l|l|l|l|}
\hline Ranks & Items & Priority Weights & Tiers \\
\hline 1 & This cell phone brand reflects me as popular \& exciting person among others & 0.404422 & Critical Item \\
\hline 2 & $\begin{array}{l}\text { While carrying \& using of this cell phone, peoples perceives me as cool, } \\
\text { young \& up to date }\end{array}$ & 0.326226 & Critical Item \\
\hline 3 & Users of this cell phone believed me as upper class and glamorous & 0.147071 & Supporting Item \\
\hline 4 & $\begin{array}{l}\text { I experience myself as good looking \& charming, while using or carrying of } \\
\text { this cell phone in social gathering }\end{array}$ & 0.1254793 & Supporting Item \\
\hline 5 & $\begin{array}{l}\text { My personality represented as friendly \& cheerful person because of my cell } \\
\text { phone brand }\end{array}$ & 0.078547 & Maintaining Item \\
\hline 6 & Peoples consider me as honest \& sincere because of my cell phone brand & 0.062901 & Maintaining Item \\
\hline 7 & I feel that my cell phone brand is considered as family oriented brand & 0.035354 & Maintaining Item \\
\hline
\end{tabular}

Tier I showed the critical items which are two in number. The item with maximum weight (0.404422) was "This cell phone brand reflects me as popular \& exciting person among others." This critical item belonged to the "Brand Personality's Excitement Dimension". The second critical item was "While carrying \& using of this cell phone, peoples perceive me as Cool, Young \& up-to-date." It has a weight value of 0.326226 . This item also belonged to the "Brand Personality's Excitement Dimension". The results suggest that organizations must spend on establishment of their Brand's Personalities specifically keeping the excitement dimensions of human characteristics at main stream.

Tier II consisted of two supporting items that supported critical items in influencing customer satisfaction. The first supporting item was "Users of this cell phone believed as Upper Class \& Glamorous." with a weight value of 0.147071. This item belonged to the brand personality's Sophistication Dimension. The second supporting item was "I experience myself as Good Looking \& Charming, while using or carrying of this cell phone brand in social gatherings." It had weight value of 0.1254793. This item belonged to the brand personality's Sophistication Dimension. From above mentioned supporting items, it is essential for cellular phones manufacturers to make significant investment in all such activities that develops and enhance image of brand's personalities of their cell phone brands so that customer satisfaction can be flourished.

Tier III consisted of 3 maintaining items starting from global weight of 0.078547 . These items were of least 
importance and can be neglected in decision making process.

\subsection{Correlation Analysis}

Correlation analysis helps to observe association amongst complete variables. Results of our study is shown in summarized form as follows

\section{Correlation Analysis}

\begin{tabular}{|c|c|c|c|c|c|}
\hline \multirow{2}{*}{$\begin{array}{l}\text { Brand Personality } \\
\text { Brand Personality } \\
\text { Correlation }\end{array}$} & \multirow{2}{*}{$\begin{aligned} \text { Gender } \\
\text { Pearson }\end{aligned}$} & \multirow{2}{*}{$\frac{\text { Age }}{1}$} & \multicolumn{3}{|c|}{ Customer Satisfaction } \\
\hline & & & $-.209 * *$ & $.341 * *$ & $.402 * *$ \\
\hline $\begin{array}{l}\text { Gender } \\
\text { Correlation }\end{array}$ & Pearson & $-.209 * *$ & 1 & $-.015^{* *}$ & $.015^{* *}$ \\
\hline $\begin{array}{l}\text { Age } \\
\text { Correlation }\end{array}$ & Pearson & $.341 * *$ & $-.015 * *$ & 1 & $.697 * *$ \\
\hline $\begin{array}{l}\text { Customer } \\
\text { Satisfaction }\end{array}$ & $\begin{array}{l}\text { Pearson } \\
\text { Correlation }\end{array}$ & $.402 * *$ & .015 & $.697 * *$ & 1 \\
\hline
\end{tabular}

${ }^{\star *}$. Correlation is significant at the 0.01 level (2-tailed).

The above results show that the Pearson Correlation $(r=0.697, p=0.000)$ indicated the degree of linear dependence between Customer Satisfaction and Customer Age. It showed the case of a perfect direct increasing and stronger linear correlation. It means that impact of customer age is positively influenced the customer satisfaction.

The second major contributor towards customer satisfaction was "impact of brand personalities". The results showed that the Pearson Correlation $(\mathrm{r}=0.402, \mathrm{p}=0.000)$ indicated the degree of linear dependence between Customer Satisfaction and Brand Personality. It means that impact of brand personality is positively influenced the customer satisfaction and have direct and linear correlation. Our research's fundamental goal was also to analyze the effect of brand personalities on customer satisfaction so that satisfaction level can be boost up. Like different scholars elaborately describe the phenomena that how impact of brand personalities can influence the customer satisfaction in positive way. Researchers (Anderson et al, 1994) both endorsed our fourth contributor results that satisfaction always capture those elements of a product or brand, which depict or encapsulate human characteristics into it.

The results showed that the Pearson Correlation $(\mathrm{r}=0.341, \mathrm{p}=0.000)$ indicated the degree of linear dependence between Brand Personality and Customer Age. It showed that as both variables are independent and their Pearson Correlation Coefficient is not large. The relationship observed between them as Linear Dependent. Average correlations obliquely demographic constructs including age factor and five traits of personality (Goldberg, et al., 1998).

\subsection{Regression Analysis}

Linear Regression is a methodology, which concerned with the relationship between a predicted variable Y and one or more causal variables indicated X. Linear regression helps in discovering the connection in the middle of reliant and autonomous variables (Hooper, Coughlan, \& Mullen, 2008).

\section{Regression Analysis}




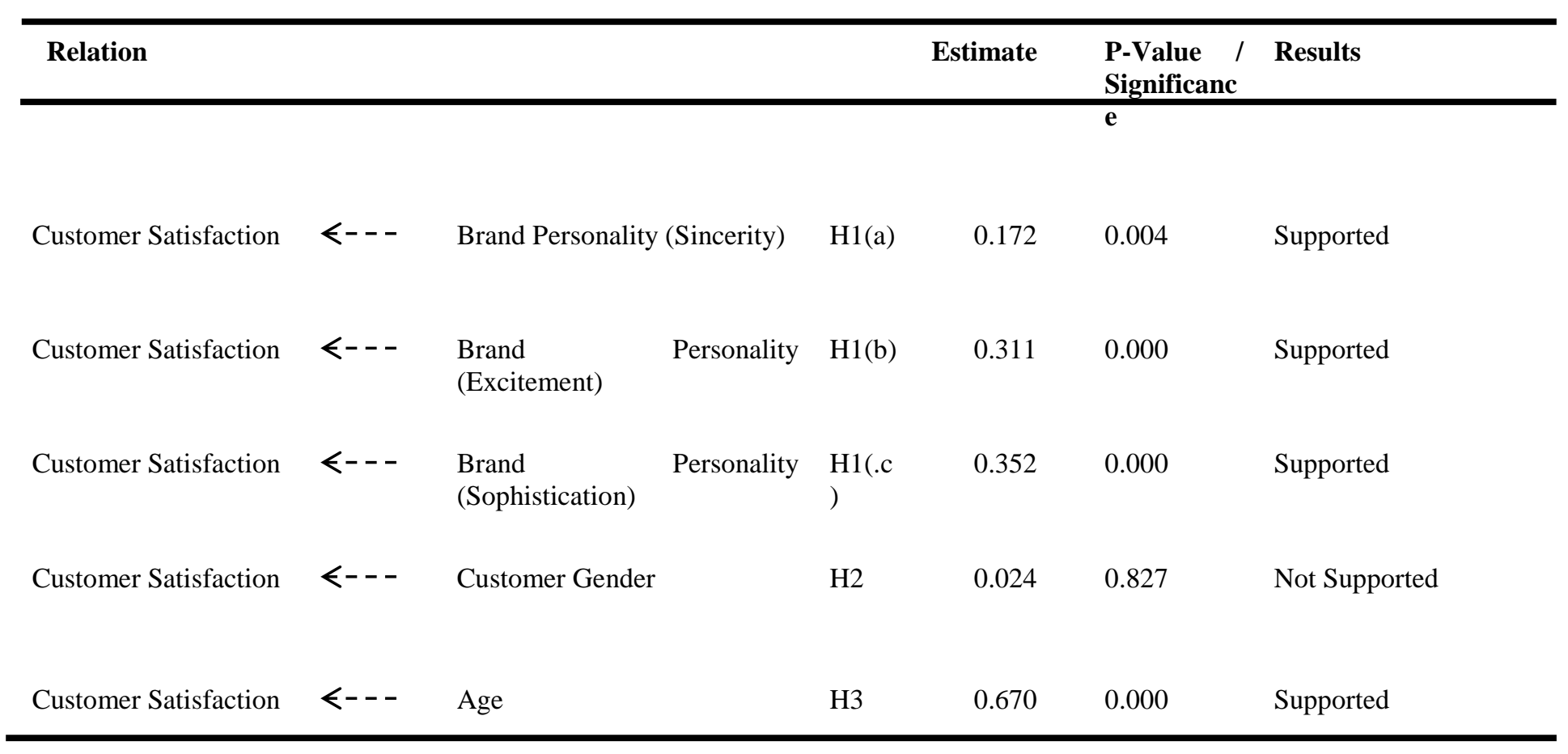

**The level of significance is 0.05 or less

H1(a) is "Sincerity in Brand will have positive impact on consumer satisfaction." Results suggested that there is significant relationship between humanistic characteristics of sincerity in brand and customer's satisfaction with the pvalue as "0.004", which is less than " 0.05 ". Hence it supported H1(a). Further, it supported our research to fit our predictive model and quantify the relationship strength between sincerity dimension of brand personality \& customer satisfaction. Loudon, \& Della Bitta, (1993) found that many determinants effect the satisfaction, which include, demographic variables expectations, personality variables and various other factors. Lin (2009) likewise found that diverse measurements of brand personality may set noteworthy effects on fulfillment in the setting of internet recreations. A reason that brand personality influences fulfillment is that brand personality can convey quality to shoppers (Brakus et al., 2009).

H1(b) is "Brand's usage Excitement will have positive impact on consumer satisfaction". Results suggested that there was highly significant relationship between Excitement dimension of brand personality and customer satisfaction with p-value as "0.000", which is less than " 0.05 ". Hence it supported H1(b). Cell Phones are mostly considered as the necessities of youth, which imagines that an update model of cell phone consider them as updated personality \& imaginative. Organizations must endorse the updated features, which resemble the humanistic attributes \& characteristics, indulging customers to find the way towards their imaginative \& daring personalities. Consequently, customer satisfaction would be increased \& they feel a reduced amount of dissonance after buying \& using of cell phones. As demonstrated in the study led by Kumar et al., (2006), a fruitful brand obliges the building of particular brand personality, which must be particularly not the same as different brands to make purchaser notice its image personality (Doyle, 1990).

H1(c) is "Brand's Sophistication will have positive impact on consumer satisfaction." Results suggested that there was highly significant relationship between Sophistication dimension of brand personality and customer satisfaction with p-value as "0.000", which is also less than " 0.05 ". Hence it supported H1(c). Thus, it supported our research to quantify relationship strength between sophistication dimension of customer satisfaction and brand personality. Some previous studies demonstrated the positive effect of brand personality and satisfaction (Robins, Caspi\& Moffitt, 2000, Magin et al, 2003,Aaker et al, 2004; Brakus et al., 2009; Lee, Back, \& Kim, 2009;). Most of peoples in Pakistan consider cell phone brands as symbol of glamorous, alluring \& higher standards of life style. Organizations must invest in their promotional activities so that they can portray a status consciousness element. Peoples tend to make 
their sub consciousness by describing their phone brand as well looking. Our respondents mainly showed their cell phone experience as a symbol of charm in social gatherings. Such sort of positive feelings definitely enhance the chances of more customer satisfaction and all of the customers would buy a product, which has matched personalities to their own personalities.

H3 is "The impacts of brand personality towards customer fulfillment increment with the purchaser's age." Results suggested that there was highly significant relationship between customer satisfaction and customer age with p-value is less than"0". Hence it supported H3. Significant correlations of demographic dimensions including age factor and the three personality dimensions in context of brand personality found by Goldberg, et al., (1998). In addition, Caruana (2002) identified that age and education are the major factors in determining the customer perceptions about satisfaction, service quality and loyalty. Generally, race factors and different gender contribute significantly in the customers purchase pattern (Yee and Sidek, 2008; O’Neal, 1998; Kang and Kim, 1998). This examination served to discover the noteworthiness of relationship between the causal and dependent variable. It supported our four hypotheses; H1(a), H1(b), H1(c) and H3.

\subsection{Moderation Analysis:}

In our research, we led to see the relationship between effects of brand personality and consumer level of satisfaction depends on demographic variables of Age and Gender. Moderator Variables affected in result of interaction of independent variable, made the zero-order correlation between the values of the slope of the customer satisfaction on the brand personality. This Moderation Analysis measure the casual relationship between customer satisfaction and brand personality by using regression coefficient.

Following table shows the results of moderating effect of demographics characteristics (Customer Gender and Age) on the relationship between customer satisfaction and brand personality.

\section{Result of Moderation Analysis}

\begin{tabular}{|c|c|c|c|c|c|c|c|c|}
\hline Moderating Variables & $\mathbf{R e}$ & & & Estimate & S.E. & $t$ & $\begin{array}{l}\text { Partial } \\
\text { Correlati }\end{array}$ & Sig \\
\hline Customer Gender & $\mathrm{CS}$ & $<--$ & BPxGEND & 0.111 & 0.135 & 0.818 & 0.058 & .415 \\
\hline Age & $\mathrm{CS}$ & $<--$ & $\mathrm{BPxAGE}$ & -0.018 & 0.009 & -1931 & -0.136 & 050 \\
\hline
\end{tabular}

H2 is "The effects of brand personality towards consumer satisfaction increase with consumer's gender." The results show that our demographic variable Gender does not significantly moderates the relationship between customer satisfaction and brand personality ( $\mathrm{p}$ value $=0.415$ ). However, the estimate value was 0.111 . It indicates that there does not exist the relationship between customer satisfaction and brand personality by using regression coefficient with interception of Gender with brand personality. Hence, it does not prove $\mathrm{H} 2$.

H3 is "The effects of brand personality towards consumer satisfaction increase with the consumer's age." The results showed that our demographic variable "Age" significantly moderates the relationship between customer satisfaction and brand personality ( $\mathrm{p}$ value $=0.050$ ). However, the estimate value was -0.018 . Our results indicated that there existed the relationship between customer satisfaction and brand personality by using regression coefficient with interception of Customer Age with brand personality. Nevertheless, the value -0.018 as an estimated value indicated that their existed a negative relationship between Independent \& dependent variables. As much as the age of our customer decreases, the impact of brand personality further increased. So, we can say that impact of brand personality towards customer satisfaction can be found in younger age. Different scholars (Henry, 2002) mentioned that more youthful individuals give careful consideration to expressive item angles than more seasoned individuals. Hence, it proves $\mathrm{H} 3$. 
Further, following results also show the moderating effect of demographics characteristics (Customer Gender and Age) on the relationship among each brand personality dimensions (Sincerity, Excitement \& Sophistication) \& customer satisfaction individually.

\section{Result of Moderation Analysis with Each Brand Dimension Individually}

\begin{tabular}{|c|c|c|c|c|c|c|c|c|}
\hline Moderating Variables & $\mathbf{R e}$ & & & Estimate & S.E. & $t$ & $\begin{array}{l}\text { Partial } \\
\text { Correlatio }\end{array}$ & Sig \\
\hline Customer Gender & $\mathrm{CS}$ & $<---$ & BP (Sinc.) x GEND & 0.044 & 0.123 & 0.358 & 0.025 & .721 \\
\hline Customer Gender & $\mathrm{CS}$ & $<---$ & BP (Excit) x GEND & 0.175 & 0.116 & 1.511 & 0.106 & .132 \\
\hline Customer Gender & $\mathrm{CS}$ & $<---$ & BP (Soph) x GEND & 0.070 & 0.105 & 0.669 & 0.047 & .504 \\
\hline Age & $\mathrm{CS}$ & $<---$ & BP (Sinc.) x AGE & 0.866 & 0.087 & 9.986 & 0.578 & .000 \\
\hline Age & $\mathrm{CS}$ & $<---$ & BP (Excit) x AGE & -0.131 & 0.056 & -2.346 & -0.164 & .020 \\
\hline Age & $\mathrm{CS}$ & $<---$ & BP (Soph) x AGE & -0.041 & 0.049 & -0.841 & 0.060 & .401 \\
\hline
\end{tabular}

Above results show that our demographic variable Gender does not significantly moderates the relationship among each brand personality dimension (Sincerity, Excitement \& Sophistication) and customer satisfaction (p value (Sincerity) $=0.721, \mathrm{p}$ value $($ Excitement $)=0.132, \mathrm{p}$ value $($ Sophistication $)=0.504)$ with estimated values as $0.044,0.175 \& 0.070$ respectively. It indicated that there does not exist the relationship between each brand personality dimension \& customer satisfaction by using regression coefficient with interception of Gender with each brand personality dimension.

Further, the results show that our demographic variable "Age" significantly moderates the relationship between brand personality's Sincerity Dimension and customer satisfaction ( $\mathrm{p}$ value $=0.000$ ) with estimate value as 0.866 . Our results indicate that there exist a relationship between brand personality's sincerity dimension \& customer satisfaction by using regression coefficient with interception of Customer Age with sincerity personality. However, the value 0.866 as an estimated value indicated that their existed a positive relationship between Independent \& dependent variable. Since the age of customer increases, sincerity dimension could be more appealing \& influencing towards satisfaction. Thus, we can conclude that customer with older age can be more inclined towards the sincerity aspect of the brand, which can be depicted by the companies in their advertisement and relationship marketing activities with their prospect customers.

On the other side, results also showed that our demographic variable "Age" significantly moderates the relationship between brand personality's Excitement Dimension and customer satisfaction ( $p$ value $=0.020$ ). However the estimate value as -0.131 . Our results indicated that there existed the relationship between brand personality's excitement dimension \& customer satisfaction by using regression coefficient with interception of Customer Age with excitement personality. Nevertheless, the value -0.131 as an estimated value indicated that their existed a negative relationship between Independent \& dependent variable. Customers of young ages can be impressed and motivated with the Excitement Dimension of their respective brands. As it is already mentioned that younger peoples make more intentions towards those products, which are self-expressive in nature \& their self-image are highly considered by 
those peoples, who are young.

\section{Conclusion \\ 5.1 Findings}

This research study throughout observed in research question of finding the ways to increase the customer satisfaction and loyalty by building of brand personalities activities so that satisfaction of customer can be encouraged. We aimed to see the insights of liaison of brand personalities with customer satisfaction. Moderating role for demographic characteristics (Gender and Age) between brand personalities and customer satisfaction are also investigated to find out any connection between them. Our research's eventual principal was to develop a conceptual framework which helps to identify the relationship between brand personality and customer satisfaction keeping moderating effect of customer gender \& age.

Prior studies indicated that brand personalities constructs proposed as forerunner of customer's loyalty. Existing literature (Brakus et al., 2009) also indicates that brand personalities reflect positivity towards customer satisfaction and loyalty. The present study also suggested that customer gender and customer age played as mechanism to increase level of satisfaction and dissatisfaction. This study further indicated the moderating role of gender and age between brand personalities \& customer satisfaction.

\subsection{Discussion}

As facts supported best part of projected hypotheses. But here exist also some omission of one of our hypothesis. Customer gender was not significant during impact of brand personality activities ( $\mathrm{p}$ value $=0.415$ ). But Customer age was highly significant during an impact of brand personality activities ( $\mathrm{p}$ value $=0.050$ ).

As soon as the impact of Brand Personalities can be observed by consumer in younger age, their level of satisfaction increased. We must notice that Sincerity, Sophistication \& Excitement characteristics of brand personality had dominant effect for increase of customer satisfaction. Our correlation analysis also strengthened our hypothesis as an increase of customer satisfaction is a resultant factor due to personality characteristics of brand and positive impact influenced the brand's imagination into mind of customer throughout consumption period of their cell phone usage. Similarly, moderating role of customer age also revealed that lesser the age, more the customer satisfaction and vice versa.

The correlation analysis showed that three dimensions (Sincerity, Excitement and Sophistication) of brand personality positively significant correlation for customer satisfaction. This is presumably because of the way that, with an end goal to satisfy buyer's necessities, cell brands ought to underline on every measurement to guarantee that the shopper will consider their image to be predominant regarding sincerity, excitement and sophistication. In the meantime, buyers with higher level of earnestness, energy and advancement of brand personality will know the cell phone mark unmistakably in light of the fact that this brand has balanced advertising projects to manufacture solid relationship in the middle of brand and fulfillment. The finding of current study is in line with study results of Lin (2009) and Guo (2003). As demonstrated in the study led by Kumar et al., (2006), a fruitful brand obliges the building of particular brand personality, which must be uniquely not quite the same as different brands to make buyer notice its image personality (Doyle, 1990).

Demographic variables partially enhance the relationship between BP and CS is a supported hypothesis. Therefore, age and different gender significantly contribute in the purchasing pattern of consumers (O'Neal, 1998; Yee and Sidek, 2008; Kang and Kim, 1998). This will help the marketers for the development of marketing campaign which will select the target groups.

Age has a significant moderating effect on BP and CS relationship. This may be due to the fact that in order to differentiate from other brands, most mobile phone brands in Pakistan emphasize the excitement and sophistication of brand personality, which makes consumers think that cellular brands are better in terms of excitement and sophistication. Therefore, this leads to full support for the moderating effect of demographic variables on the relationship between $\mathrm{BP}$ and $\mathrm{CS}$. 
Marketing Managers must develop ATL and BTL activities in line with their brand's human psychology. Ultimately, the customer will accept it permanently and will not scattered his satisfaction cum loyalty level of affection with brand. On the other sides, proposed conceptual framework suggests that building the personalities of cell phone brand is useful to reap the benefits of customer satisfaction.

\subsection{Theoretical contribution}

Our research supports previous work to reveal the impact of brand personality activities on customer satisfaction and loyalty. However, we have observed the role of customer age and gender in this relationship. Gender significantly affects ability and integrity perception verified by the literature related to social psychology and personality (Chen and Dhillon, 2003).

Incidentally, we find that the impact of customer age on impact of brand personality was meaningful and really considerable, i.e, $\mathrm{p}$ value $=0.050$. Additionally, customer age had moderating impact between brand personality and customer satisfaction. Actually, this finding revealed the element of satisfaction or dissatisfaction, which can arrives as an outcome of brand personality's activities. We investigated influence of sincerity, excitement \& sophistication dimension of human personality as the constructs of brand personality and tested to see whether they have tendency to maximize the level of customer satisfaction.

It shows that consumers will be more likely to be satisfied if they believe that a brand has a sincere, exciting and mature personality traits. In addition, it is found that the dimensions of excitement and sophistication have a greater impact on consumer satisfaction than other dimensions. It may need to keep the company's branded phones up to date, imaginative, charming and daring.

By and large, the consequences of this examination gave urging exact bolster both to hypothesis improvement and also for speculated directing impacts of demographic qualities on the relationship between brand personality and consumer satisfaction. In a nutshell, our research had a forceful view of human personality in association with a brand.

\subsection{Managerial Implications}

Our research had some managerial insinuations. Foremost, it entailed that all customers and consumers encounter brands with their personality traits or characteristics. Most of research indicated that a brand personality considered as standard for satisfaction of consumer and loyalty. Marketers should surf their means to increase activities of brand personality of their products. As we already discussed that it acts as mechanism which can reduce satisfaction \& dissatisfaction and vice versa. So, they must focus on the activities for indulging human characteristics into their brands in order to strengthen their brand personalities.

The most grounded brands are those with the most all around characterized traits. Such brands can separate themselves by the way they identify with customers as much as by practical or different viewpoints. Such enhancing efforts for brand personalities in study for pursuance customers after buying of high-association products. Brand managers and promotion organizers have long believed that the separation between brands and customers. In addition, product managers can investigate changes in demand and demographic characteristics in the marketing mix to execute micro-marketing procedures. Emphasizing specific personality qualities can also strengthen or undermine the aggressive position of the brand. Therefore, savvy marketing practitioners can use our research to understand the role of their brand personality in building consumer relationships, and will use this learning method to maximize brand appeal and gain great value globally in term of customer satisfaction and retention rate.

Under the matter of mobile phones, it was observed that mobile phone consumers in study showed more satisfaction. It revealed the fact that in case of a product of high-involvement like a cell phone, consumers mainly think about the brands that appeals consumers really engaged and occupied their attention rather than act in a real situation and repeat a purchase. As a result, advertisers and brand marketers should focus on the activities for fruitful brand personality's activities which promote and give confidence to customers behaviorally side by side attitudinally at the P-O-P to 
maximize sales and revenues for their companies.

\section{Limitations and future research directions}

Age of our respondents affected our results to some extent. Only 6.9\% of our respondents ages fall between 35-45 Years. But it is only due to the nature of High-Technology oriented product, which is mainly used by young peoples in Pakistan. On the other side, we investigated only one product of high involvement / high- technological oriented (i.e cell phone). Other high and sophisticated technical products can be checked to verify the impact of our brand personalities. Another limitation, which can be faced by researcher that each brand confronted distinctive circumstances because of different aspects consisting country of origins \& different cultural contexts.

Future research can address the impact of marketing mix on customer satisfaction and see how such variable influence consumer's purchase intention. Future researchers can see the impact of brand personalities on "pre-purchase stage" by using the prospect theory in order to measure "perceived risks" and "perceived gains" face by customers and how it can increase customer satisfaction and loyalty. Researchers may also address the impact of brand personalities on satisfaction during decision making at shop or point of purchase.

\section{References}

Aaker, D.A. \& Biel, A. (1993), Brand Equity and Advertising: Advertising's Role in building Strong Brands, Lawrence Erlbaum Associates, Inc., Mahwah, NJ.

Aaker, J., Fournier, S., \&Brasel, S. A. (2004). When good brands do bad? Journal of Consumer Research, 31(1), 1-16.

Anderson, Eugene W., ClaesFornell, and Donald R. Lehmann (1994), Customer Satisfaction, Market Share and Profitability: Findings from Sweden, Journal of Marketing, 58 (July), 53-66.

Awad, T. A. (2011). Environmental segmentation alternatives: buyers' profiles and implications. Journal of Islamic Marketing, Vol. 2 No.1, pp.55-73.

Batra, R., Lehman, R., \& Singh, D. (1993). The brand personality component of brand goodwill: some antecedents and consequences. Brand equity and advertisingpp. 83-96. New Jersey: Lawrence Erlbaum Associates.

Bauman, C., Burton, S., and Elliot, G. (2005). Determinants of customer loyalty and share wallet in retail banking. Journal of Financial Service Marketing, Vol. 9 No.3, pp. 231-48.

Brakus, J.J., Schmitt, B. H., \&Zarantonello, L. (2009). Brand experience: what is it? How is it measured? Does it affect loyalty?Journal of Marketing, 73(3), pp. 52-68. doi: 10.1509/jmkg.73.3.52

Caprara, G. V, Barbaranelli, C, \& Guido, G. (2001). Brand personality: how to make the metaphor fit? Journal of Economic Psychology, Vol. 22, pp. 377-395.

Cardozo, R. N. (1965). An experiential study of consumer effort, expectation, and satisfaction. Journal of Marketing Research, 5(2), 244-249.

Caruana, A. (2002). Service loyalty: the effects of service quality and the mediating role of customer satisfaction. European Journal of Marketing, Vol. 36 No. 7/8, pp. 811-828.

Chen, S. C., and Dhillon, G. S. (2003). Interpreting dimensions of consumer trust in commerce. Information Technology and Management, Vol. 4, pp. 203-318.

Cooil, B., Keiningham, T. L., Aksoy, L., and Hsu Michael. (2007). A longitudinal analysis of customer satisfaction and share of wallet: investigating the moderating effect of customer characteristics. Journal of Marketing, Vol. 71, pp. 67-83.

Doyle, P. (1990). Building successful brands: the strategic options. Journal of Consumer Marketing, 7(2), 5-20.

Durgee, J. F. (1988). Understanding brand personality, The Journal of Consumer Marketing, 5(3), pp. 21-25.

Floh, A., \&Treiblmaier, H. (2006). What Keeps the E-banking Customer Loyal? A Multigroup Analysis of the Moderating Role of Consumer Characteristics on E-loyalty in the Financial Service Industry. Journal of Electronic Commerce Research, 7(2), 97-110.

Gilbert, F. W., \& Warren, W. E. (1995). Psychographic constructs and demographic segments, Psychology \& Marketing, Vol. 12, pp. 223-237

Goldberg, L. R., Sweeney, D., Merenda, P. F. and Hughes, J. E. (1998). Demographic variables and personality: the effects of gender, age, education, and ethnic/racial status on self-descriptions of personality attributes. Personality and Individual Differences, Vol. 24, pp. 393-403.

Govers, P.C.M. \&Schoormans, J.P.L. (2005), Product personality and its influence on consumer preference, Journal 
of Consumer Marketing, Vol. 22 No. 4, pp. 189-97.

Grohmann, B. (2009). Gender dimensions of brand personality, Journal of Marketing Research, 46(1), pp. $105-119$. doi: $10.1509 / j m k r .46 .1 .105$

Guo, L.-J. (2003), The Effects of Personality Trait and Brand Personality on Brand Preference, Graduate Institute of Management Science, National Chiao Tung University, Hsinchu.

Henry, P. (2002), Systematic variation in purchase orientations across social classes. Journal of Consumer Marketing, Vol. 19 No. 5, pp. 424-38.

Holt, D. (1995). How consumers consume: a typology of consumption. Journal of Consumer Research, 22(1), 1-16.

Homburg, C \&Giering, A. (2001). Personal characteristics as moderators of the relationship between customer satisfaction and loyalty - an empirical analysis. Psychology \& Marketing, Vol. 18 No. 1, pp. 43-66.

Hooper, D., Coughlan, J., \& Mullen, M. (2008). Structural equation modeling: guidelines for determining model fit. Articles, 2.

Howard, J. A., \&Sheth, J. N. (1969). The theory of buyer behavior. New York: Wiley.

Jasper, C. R., \&Lan, P. R. (1992). Apparel catalog patronage: demographic, lifestyle and motivational factors, Psychology \& Marketing, Vol. 9, pp. 275-296.

Johnson, L. W., Soutar, G. N., \& Sweeney, J. C. (2000). Moderators of the Brand Image/Perceived Product Quality Relationship, Journal of Brand Management, 7(6), pp. 425-433.

Kang, J. and Kim, Y. K. (1998). Ethnicity and acculturation: influences on Asian American consumer's purchase decision making for social clothes. Family and Consumer Sciences Research Journal, Vol. 27 No. 1, pp. 91115.

Krishnamurthi, L. \& Raj, S.P., 1991. An empirical Analysis of the Relationship between Brand Loyalty and Customer Price Elasticity, Marketing Science 10, 2, pp. 172-183.

Kumar, R., Luthra, A. \&Datta, G. (2006), Linkages between brand personality and brand loyalty: a qualitative study in an emerging market in the Indian context, South Asian Journal of Management, Vol. 13 No. 2, pp. 11-35.

Landon, E. L. (1974). Self-concept, ideal self-concept and consumer purchase intentions, Journal of Consumer Research, 1(2), pp. 44-51.

Lee, Y. K., Back, K. J., \& Kim, J. Y. (2009). Family Restaurant Brand Personality and ITS Impact on Customer's Emotion, Satisfaction, and Brand Loyalty. Journal of Hospitality and Tourism Research, 33(3), 305-328.

Levy, S. (1959). Symbols for sales. Harvard Business Review, 37(4), 117-124.

Lin, C. P. (2009). Learning Online Brand Personality and Satisfaction: The Moderating Effects of Gaming Engagement. International Journal of Human-Computer Interaction, 25(3), 220-236.

Loudon, D. L \& Della Bitta, A. J. (1993).Consumer Behaviour: Concepts and Applications. (Fourth edition), McGraw-Hill, NY.

Magin, S., Algesheimer, R., Huber, F., \& Herrmann, A. (2003). The impact of brand personality and customer satisfaction on customer's loyalty: theoretical approach and findings of a causal analytical study in the sector of Internet service providers. Electronic Markets, 13(4), 294-308.

Malhotra, N.K., Kim, S.S. \&Patil, A. (2006), Common method variance in IS research: a comparison of alternative approaches and a reanalysis of past research, Management Science, Vol. 52 No. 12, pp. 1865-1883.

Matzler, K., Wurtele, A., \&Renzl, B. (2006). Dimension of price satisfaction: a study in the retail banking industry. International Journal of Bank Marketing, Vol.24 No.4, pp. 216-231.

Mengxia, Z. (2007), Impact of brand personality on PALI: a comparative research between two different brands, International Management Review, Vol. 3 No. 3, pp. 36-46.

Mittal, V. and Kamakura, W. (2001). Satisfaction, repurchase intent, and repurchase behavior: investigating the moderating effect of customer characteristics. Journal of Marketing Research, Vol. 38 (February) pp. 131-42.

Oliver, R. L. (1981). Measurement and evaluation of satisfaction processes in retail settings. Journal of Retailing, 57(3), 25-48.

O’Neal, G. S. (1998). African American women's professional dress as expression of ethnicity. Journal of Family and Consumer Sciences, pp. 28-33.

Park, I., Cho, J. \& Rao, H.R. (2012), The effect of pre- and post-service performance on consumer evaluation of online retailers, Decision Support Systems, Vol. 52 No. 2, pp. 415-426.

Plummer, J. (1985). How personality makes a difference, Journal of Advertising Research, 24(6), pp. $27-31$.

Robins, R. W., Caspi, A., \& Moffitt, T. E. (2000). Two personalities, one relationship: Both partners' personality traits 
shape the quality of their relationship.Journal of Personality and Social Psychology, 79(2), 251-159.

Saaty T (1990) ; How to make a decision: The analytic hierarchy process, Operational Research, Volume 48, Issue 1 Pages 9-26

Schmidt, M.J., \&Hollensen, S. (2006). Marketing research- An international approach. London: Prentice Hall.

Siguaw, J. A., Mattila, A., \& Austin, J. R. (1999). The brand personality scale: An application for restaurants, Cornell Hotel and Restaurant Administrative Quarterly, 40(3), pp. 48-55.

Slama, M. E. and Tashlian, A. (1985). Selected socio-economic and demographic characteristics associated with purchasing involvement. Journal of Marketing, Vol. 49, pp. 72-82

Smith, J., and Baltes, P. B. (1990). Wisdom-related knowledge: age/cohort differences in response to life planning problems. Development Psychology, Vol. 26, pp. 494-505.

Solomon, M., Bamossy, G., Askegaard, S. \& Hogg, M.K. (2006), Consumer Behavior: a European perspective, 3rd ed., Prentice Hall, Harlow.

Sung, Y. J., \& Kim, J. (2010). Effects of Brand Personality on Brand Trust and Brand Affect, Psychology \& Marketing, 27(7), pp. 639-661.

Venkatesh, V., Moris, M. G., and Ackerman, P. L. (2001). A longitudinal field investigation of gender differences in individual technology adoption decision-making process. Organisational Behavior and Human Decision Processses, Vol. 83 No. 1, pp. 33-60.

Wang, F., \& Head, M. (2007). How can the web help build customer relationships? An empirical study on e-tailing. Information \& Management, 44(2), 115-129.

Yee, W. F., and Sidek, Y. (2008). Influence of brand loyalty on consumer sportswear. International Journal of Economics and Management. Vol. 2 No.2, pp. $221-236$.

Zeithmal, V. A. (1996). The new demographics \& market fragmentation, Journal of Marketing, Vol. 49, pp. 64-75.

\section{Corresponding author}

Prof. Dr. Hayat M. Awan can be contacted at: hma@aumc.edu.pk. 